\title{
Quality of Life in Thalassemia Major Patients: Reliability and Validity of Indonesian Version of TranQol Questionnaire
}

\author{
Billy Ng Setiawan Rachmat Poengoet, Ellyana Sungkar, Tri Damiati Pandji
}

Department of Physical Medicine and Rehabilitation, Faculty of Medicine, Universitas Padjadjaran-Dr. Hasan Sadikin General Hospital, Bandung

\begin{tabular}{|c|c|}
\hline \multirow[t]{3}{*}{ Abstract } & $\begin{array}{l}\text { Objective: To determine the validity and reliability of TranQol questionnaire } \\
\text { that has been translated into Indonesian to be used in Indonesian thalassemia } \\
\text { major patients. The quality of life problems among these patients can be } \\
\text { detected earlier because TranQol is more precise compared to the Pediatric } \\
\text { Quality of Life Inventory (PedsQLTM), World Health Organization Quality of } \\
\text { Life Instruments (WHOQOL), and SF-36 Questionaire. }\end{array}$ \\
\hline & $\begin{array}{l}\text { Methods: This study was conducted in Bandung, Indonesia from October } \\
2015 \text { to March } 2016 \text { and used a standard "forward-backward" translation } \\
\text { procedure. It involved } 60 \text { adults and } 73 \text { children who are thalassemia major } \\
\text { patients, and } 71 \text { parents of patients in Dr. Hasan Sadikin General Hospital. } \\
\text { TranQol was processed through forward and backward translation approach } \\
\text { and evaluation was conducted by the TranQol author. After the translation } \\
\text { process, a cognitive debriefing was performed and the translated TranQol } \\
\text { was tested to all subjects. }\end{array}$ \\
\hline & $\begin{array}{l}\text { Results: Cronbach's alpha }>0.7 \text { was used for all TranQol categories. Front } \\
\text { validity and content validity testing was performed. The internal validity } \\
\text { results showed that some questions were not valid. }\end{array}$ \\
\hline $\begin{array}{l}\text { Received: } \\
\text { May 5, } 2017\end{array}$ & $\begin{array}{l}\text { Conclusions: TranQol reliability in Indonesian language for every category is } \\
\text { good. Validity for TranQol in Indonesian language shows that the translated }\end{array}$ \\
\hline $\begin{array}{l}\text { Revised: } \\
\text { July 21, } 2017\end{array}$ & TranQol is not quite suitable that it still cannot be used. \\
\hline \multirow{2}{*}{$\begin{array}{l}\text { Accepted: } \\
\text { August 30, } 2017\end{array}$} & Keywords: TranQol Indonesia, validity Indonesia, reliability Indonesia \\
\hline & $\begin{array}{l}\text { pISSN: 2302-1381; eISSN: 2338-4506; http://doi.org/10.15850/ijihs.v5n2.1011 } \\
\text { IJIHS. 2017;5(2):75-9 }\end{array}$ \\
\hline
\end{tabular}

\section{Introduction}

Thalassemia is a monogenic disease that is caused by the disturbance in the hemoglobin formation that is observed around the world. ${ }^{1}$ India has alpha thalassemia cases of $12.9 \%$ and beta thalassemia cases of $3-4 \% 0^{2,3}$ Beta thalassemia is mostly found in Mediteranian countries, Middle East, Middle Asia, India, South China and countries along North Africa and South America beach. ${ }^{4}$

The Indonesian Thalassemia FoundationAssociation of Thalassemia Patients' Parents or known as YTI-POPTI (Yayasan Thalassemia

Correspondence:

Billy Ng Setiawan Rachmat Poengoet, Department of Physical Medicine and Rehabilitation, Faculty of Medicine, Universitas Padjdajaran-Dr. Hasan Sadikin General Hospital

Jl. Pasteur No. 38, Bandung, Indonesia

e-mail: billyscorp@yahoo.com
Indonesia-Perhimpunan Orang Tua Pasien Thalassemia) has reported increased number of thalassemia patients in Indonesia to 7,028 in 2015. ${ }^{5}$ The prevention of thalassemia is difficult because of its genetic nature.

Blood transfusion and iron chelating agent increase the survival rate of thalassemia major patients. They will have more opportunities to reach higher education, to work, and to have a better quality of life. In addition, patients may experience complications from the procedure (i.e: osteoporosis, infertility and psychiatric problem). Iron absorption problem in guts and blood transfusion can lead to chronic health problems due to iron acumulation in the body. These will affect thalassemia patients' quality of life.

Research has been done in many countries to evaluate thalassemia patients' quality of life. 
Some questionnaires are already used to assess it, such as Pediatric Quality of Life Inventory (PedsQL ${ }^{\mathrm{TM}}$ ), the World Health Organization's Quality of Life Instruments (WHOQOL), and SF-36 Questionaire. ${ }^{6-11}$ These are not specific enough for thalassemia patients.

TranQol was created and published on July 22,2013 . TranQol is a self-report tool used in children, adult, parents or proxy. ${ }^{12,13}$ There are 4 groups of questions in this tool: physical health, emotional health, family, school and career. There is only one question regarding the sexual aspect in this tool. The original TranQol have been evaluated for its reliability and validity. It is already acknowledged as a valid and reliable tool to be used specifically for thalassemia patients.

Original English TranQol cannot be used in Indonesia because the different interpretation will reduce its validity and reliability. Hence, its has to be translated and evaluated for its validity and reliability before it can be used in Indonesia.

\section{Methods}

A standard forward and backward translation procedure was performed by native speakers for the source and target languages after approval was gained from the author and Mapi Research Institute. The procedure was based on Linguistic Validation of a Patient Reported Outcome Measure guideline. After that, a cognitive debriefing was conducted. The result was consulted to the author. The final TranQol in Indonesian language was then distributed for a try out among thalassemia patients. This involved 60 adult and 73 child thalassemia major patients and 71 parents, as proxy, who were selected randomly. The study has received ethical approval from the Ethics Committee of Dr. Hasan Sadikin General Hospital, Bandung and Health Research Ethics Committee Faculty of Medicine Universitas Padjadjaran.

The statistical analyses were performed using a computerized program. Cronbach's alpha was used to assess the reliability and the internal consistency of the questionnaire. Validity was evaluated using the Spearman correlation.

\section{Results}

The mean age of the respondents in this study was 12.60 for children, 23.34 for adults, and 39.87 for parents and proxy. Blood transfusion frequency (in weeks) for children was 3.73 and 4.95 for adults. The reliability of TranQol in Indonesian language was tested by Cronbach's alpha. The reliability was proven good with $>0.7$ Cronbach's alpha for children, adults, parents, and proxy (i.e. 0.806 for child, 0.877 for adult, 0.926 for parent, and 0.755 for proxy).

Validity was tested by correlating each with the total score. TranQol in Indonesian validity testing included all 38 questions for parents but not included 9 of 28 questions in children, 10 of 36 questions for adults, 12 of 28 questions for proxy because those questions were left blank. This interfered the correlation with total score. Those unanswered questions could be not included in the evaluation based on the result of a discussion with the author of TranQol (Table 3 and 4).

\section{Discussion}

The questions in the TranQol are more targeted for thalassemia patients when compared to Pediatric Quality of Life Inventory (PedsQL ${ }^{\mathrm{TM}}$ ), the World Health Organization Quality of Life Instruments (WHOQOL), and also the SF-36 Questionaire. Some questions in the TranQol ask about the direct impact of thalassemia to the patients's life. The impact of regular transfusion and iron removal treatment that are specific for thalassemia were asked too. The benefit is that thalassemia patients's quality of life problems can be detected earlier, making early intervention possibler for optimal result.

TranQol in Indonesian language for children did not include all questions. Questions 3, $6,7,8,12,13,18,22$ and 23 are excluded. Question number 3 is about pain, 6 is about social activity, 7 is about painful examination, 18 is about negative effects of thalassemia, 22 and 23 are about decision of thalassemia care which were considered not specific and hard to be understood by children.

Table 1 Subject Characteristics

\begin{tabular}{lccc}
\hline & Children & Adult & $\begin{array}{c}\text { Parent or } \\
\text { Proxy }\end{array}$ \\
\hline $\mathrm{N}$ & 73 & 60 & 71 \\
Mean & 12.60 & 23.34 & 39.87 \\
Median & 13 & 22 & 39 \\
Minimum & 7 & 19 & 23 \\
Maximum & 17 & 39 & 62 \\
\hline
\end{tabular}


Table 2 Internal Validation for Children and Proxy

\begin{tabular}{lcclcc}
\hline \multicolumn{1}{c}{ Children } & $\begin{array}{c}\text { Spearman } \\
(\mathbf{R})\end{array}$ & p Value & Proxy & $\begin{array}{c}\text { Spearman } \\
\text { (R) }\end{array}$ & p Value \\
\hline Question 1 and score & 0.228 & 0.052 & Question 1 and score & 0.5919 & 0.0000 \\
Question 2 and score & 0.531 & 0.000 & Question 2 and score & 0.5550 & 0.0000 \\
Question 4 and score & 0.431 & 0.000 & Question 4 and score & 0.6481 & 0.0000 \\
Question 5 and score & 0.563 & 0.000 & Question 5 and score & 0.7570 & 0.0000 \\
Question 9 and score & 0.442 & 0.000 & Question 7 and score & 0.5764 & 0.0000 \\
Question 10 and score & 0.604 & 0.000 & Question 8 and score & 0.6085 & 0.0000 \\
Question 11 and score & 0.593 & 0.000 & Question 9 and score & 0.6007 & 0.0000 \\
Question 14 and score & 0.594 & 0.000 & Question 10 and score & 0.6619 & 0.0000 \\
Question 15 and score & 0.332 & 0.004 & Question 11 and score & 0.5892 & 0.0000 \\
Question 16 and score & -0.017 & 0.885 & Question 12 and score & 0.6237 & 0.0000 \\
Question 17 and score & 0.266 & 0.023 & Question 13 and score & 0.7498 & 0.0000 \\
Question 19 and score & 0.122 & 0.304 & Question 14 and score & 0.7178 & 0.0000 \\
Question 20 and score & 0.519 & 0.000 & Question 15 and score & 0.4486 & 0.0001 \\
Question 21 and score & 0.379 & 0.001 & Question 18 and score & 0.4660 & 0.0000 \\
Question 24 and score & 0.515 & 0.000 & Question 22 and score & 0.3997 & 0.0006 \\
Question 25 and score & 0.743 & 0.000 & Question 23 and score & 0.2985 & 0.0121 \\
Question 26 and score & 0.669 & 0.000 & & & \\
Question 27 and score & 0.578 & 0.000 & & & \\
Question 28 and score & 0.509 & 0.000 & & & \\
\hline
\end{tabular}

Question number 8 about feeling different from others, 12 about feeling angry, 13 about feeling sad are subjective and cannot be well understood by children under 10 years of age.

TranQol in Indonesian language for adults did not include questions $10,15,24,25,31$, $32,33,34,35$, and 36. Question number 10 about thlassemia impact in preventing activity, 15 about feeling anxious, 24 about feeling different with others were viewed to be not specific enough to be understood that it was decided not to include them in the Indonesian version of TranQol.Question 25 about sexual aspect was not answered by many participants because many respondents were not married yet or they consider the question is too sensitive from the perspective of Indonesian culture, which considers discussion on sexual topic as taboo. Questions number 31, 32, 33 on school and 34, 35, 36 on work were not answered by many respondents because most of them did not continue their education to the higher education level or work due to their disability.
TranQol in Indonesian language for proxy did not include questions $3,6,16,17,19,20$, $21,24,25,26,27$, and 28. Question number 3 on pain felt by patient, 6 on social activity, 16 family support, and 17 on friends support were considered to be not specific so they would be hard to answer. Questions number 19, 20, 21 on relation between patient and his/her family were not answered because proxy did not have exact knowledge, patient had lost his/her parents, or patient was not carried by his/her parent anymore. Parents were also considered proxy that it may lead to confusion. Question number 24 regarding the child opinion about family economic problem was not answered by many because they did not know the answer or the children were too young to have opinion about it. Question number 25, 26, 27, 28 about school are not relevant for those who do not get higher education.

All questions in the Indonesian version of TranQol for parents were well understood and answered well by all the respondents. Spearman correlation analysis was done 
Table 3 Internal Validity for Adults and Parents

\begin{tabular}{|c|c|c|c|c|c|}
\hline Adult & $\begin{array}{c}\text { Spearman } \\
\text { (R) }\end{array}$ & p Value & Parent & $\begin{array}{c}\text { Spearman } \\
\text { (R) }\end{array}$ & p Value \\
\hline Question 1 and score & 0.168 & 0.203 & Question 1 and score & 0.2599 & 0.0286 \\
\hline Question 2 and score & 0.056 & 0.670 & Question 2 and score & 0.4118 & 0.0004 \\
\hline Question 3 and score & 0.486 & 0.000 & Question 3 and score & 0.3286 & 0.0051 \\
\hline Question 4 and score & 0.399 & 0.002 & Question 4 and score & 0.5990 & 0.0000 \\
\hline Question 5 and score & 0.479 & 0.000 & Question 5 and score & 0.5503 & 0.0000 \\
\hline Question 6 and score & 0.115 & 0.386 & Question 6 and score & 0.1765 & 0.1438 \\
\hline Question 7 and score & 0.593 & 0.000 & Question 7 and score & 0.2694 & 0.0231 \\
\hline Question 8 and score & 0.491 & 0.000 & Question 8 and score & 0.5901 & 0.0000 \\
\hline Question 9 and score & 0.394 & 0.002 & Question 9 and score & 0.5800 & 0.0000 \\
\hline Question 11 and score & 0.546 & 0.000 & Question 10 and score & 0.6397 & 0.0000 \\
\hline Question 12 and score & 0.514 & 0.000 & Question 11 and score & 0.6187 & 0.0000 \\
\hline Question 13 and score & 0.541 & 0.000 & Question 12 and score & 0.5030 & 0.0000 \\
\hline Question 14 and score & 0.452 & 0.000 & Question 13 and score & 0.5341 & 0.0000 \\
\hline Question 16 and score & 0.272 & 0.037 & Question 14 and score & 0.4115 & 0.0004 \\
\hline Question 17 and score & 0.049 & 0.711 & Question 15 and score & 0.5333 & 0.0000 \\
\hline Question 18 and score & 0.681 & 0.000 & Question 16 and score & 0.5017 & 0.0000 \\
\hline Question 19 and score & 0.719 & 0.000 & Question 17 and score & 0.5155 & 0.0000 \\
\hline Question 20 and score & 0.500 & 0.000 & Question 18 and score & 0.4975 & 0.0000 \\
\hline Question 21 and score & 0.669 & 0.000 & Question 19 and score & 0.7320 & 0.0000 \\
\hline Question 22 and score & 0.693 & 0.000 & Question 20 and score & 0.5324 & 0.0000 \\
\hline Question 23 and score & 0.203 & 0.120 & Question 21 and score & 0.5931 & 0.0000 \\
\hline Question 26 and score & 0.181 & 0.166 & Question 22 and score & 0.4294 & 0.0002 \\
\hline Question 27 and score & 0.522 & 0.000 & Question 23 and score & 0.6494 & 0.0000 \\
\hline Question 28 and score & 0.438 & 0.000 & Question 24 and score & 0.5892 & 0.0000 \\
\hline Question 29 and score & 0.453 & 0.000 & Question 25 and score & 0.2858 & 0.0165 \\
\hline \multirow[t]{13}{*}{ Question 30 and score } & 0.577 & 0.000 & Question 26 and score & 0.3312 & 0.0281 \\
\hline & & & Question 27 and score & 0.5150 & 0.0000 \\
\hline & & & Question 28 and score & 0.5376 & 0.0000 \\
\hline & & & Question 29 and score & 0.6093 & 0.0000 \\
\hline & & & Question 30 and score & 0.6099 & 0.0000 \\
\hline & & & Question 31 and score & 0.5402 & 0.0000 \\
\hline & & & Question 32 and score & 0.2301 & 0.0572 \\
\hline & & & Question 33 and score & 0.1870 & 0.1212 \\
\hline & & & Question 34 and score & 0.6671 & 0.0000 \\
\hline & & & Question 35 and score & 0.5765 & 0.0000 \\
\hline & & & Question 36 and score & 0.5977 & 0.0000 \\
\hline & & & Question 37 and score & 0.5089 & 0.0000 \\
\hline & & & Question 38 and score & 0.6412 & 0.0000 \\
\hline
\end{tabular}


for every question with the total score after selection of questions. Results of correlation analysis in this study show that 2 questions in TranQol for children are not valid (Table 3). Question number 16 about family support seems to be not specific so that it is difficult to answer. Question number 19 about decision on treatment is too hard to be understood by children and they usually follow their parents' decision. Question number 6 in TranQol for adult is not valid. Question number 1 on sleep difficulty, 2 on pain, 6 on ability to do activity, 17 on telling thalassemia to others, 23 on guilty feeling when do not follow the treatment will be better understood if they are simplified and made more specific. Question number 6 on

\section{References}

1. Weatherall DJ. Thalassemia as a global health problem: recent progress towards its control in the developing countries. Ann N Y Acad Sci. 2010;1202(1):17-23.

2. Nadkarni A, Phanasgaonkar S, Colah R, Mohanty D, Ghosh K. Prevalence and molecular characterization of alpha-thalassemia syndromes among Indians. Genet Test. 2008;12(2):177-80.

3. Mohanty D, Colah RB, Gorakshakar AC, Patel RZ, Master DC, Mahanta J, et al. Prevalence of $\beta$-thalassemia and other haemoglobinopathies in six cities in India: a multicentre study. J Community Genet. 2013;4(1):33-42.

4. Flint J, Harding RM, Boyce AJ, Clegg JB. The population genetics of the haemoglobinopathies. Baillieres Clin Haematol. 1998;11(1):1-51.

5. Stastitical data of thalassemia patients in Indonesia. Yayasan Talasemia IndonesiaPerhimpunan Orangtua Penderita Talasemia Indonesia; 2015. [cited 2015 Jan 10]. Available from: http://www.thalassaemia-yti.org/.

6. Ayoub MD, Radi SA, Azab AM, Abulaban AA, Balkhoyor AH, Bedair S-eW, et al. Quality of life among children with beta-thalassemia major treated in Western Saudi Arabia. Saudi Med J 2013;34(12):1281-6.

7. Jafari H, Lahsaeizadeh S, Jafari P, Karimi M. Quality of life in thalassemia major: Reliability and validity of the Persian version of the SF-36 questionnaire. J Postgrad Med. 2008;54(4):273-5.

8. Ansari S, Baghersalimi A, Azarkeivan A, Nojomi M, Hassanzadeh Rad A. Quality of life feeling disturbed by their child treatment and number 33 on support from friends might be difficult to understand due to their unspesific nature. All selected TranQol questions for proxy are valid.

In conclusion, the reliability of Indonesian version TranQol is good but many questions from each category are still not valid. Further studies are needed to validate the translated TranQol before it can be used in Indonesia. It can be considered to translate TranQol by a certified translator. TranQol for proxy has the highest number of unanswered questions. Decreased concentration and motivation may be caused by the fact that parents had to answere TranQol for proxy in succession.

in patients with thalassemia major. Iran J Ped Hematol Oncol. 2014;4(2):57-63.

9. Wahyuni MS, Ali M, Rosdiana N, Lubis B. Quality of life assessment of children with thalassemia. Paediatr Indones. 2011;51(3):163-9.

10. Haghpanah S, Nasirabadi $S$, Ghaffarpasand F, Karami R, Mahmoodi M, Parand S, et al. Quality of life among Iranian patients with beta-thalassemia major using the SF-36 questionnaire. Sao Paulo Med J. 2013;131(3):166-72.

11. Ismail M, Chun CY, Yusoff NAM, Shahar S, Manaf ZA, Rajikan R, et al. Quality of life among thalassaemia children, adolescent and their caregivers. Sains Malaysiana. 2013;42(3):37380.

12. Klaassen RJ, Alibhai S, Allen MK, Moreau K, Pulcini MM, Forgie M, et al. Introducing the tran qol: a new disease-specific quality of life measure for children and adults with thalassemia major. J Blood Disorders Transf [serial on the internet]. 2013 Jun [cited 2015 Jan 12];5(150):[about 5p.]. Available from: https://www.omicsonline.org/introducingthe-tran-qol-a-new-disease-specific-qualityof-life-measure-for-children-and-adults-withthalassemia-major-2155-9864.1000150. php?aid=15595.

13. Klaassen RJ, Barrowman N, Merelles-Pulcini M, Vichinsky EP, Sweeters N, Kirby-Allen M, et al. Validation and reliability of a disease-specific quality of life measure (the TranQol) in adults and children with thalassaemia major. BJH. 2014;164(3):431-7. 